\title{
Women Superintendent Research: 2014-2016 Dissertation Literature Review Content Analysis
}

\author{
By Gloria Gresham ${ }^{*} \&$ Pauline Sampson ${ }^{\dagger}$
}

In the United States (U.S.), women are drastically underrepresented in the role of school superintendent. Women who seek the job face overwhelming barriers and exhibit characteristics different from men causing challenges in obtaining the superintendency. In this study, a content analysis was conducted of the 43 U.S. dissertations relating to women superintendents located in the ProQuest database for the years of $2014-2016$. Nine major themes mentioned in a range of 20 to 36 dissertations or (47\% to 84\%) were discovered: low numbers of women superintendents, gender inequity, history of women superintendents, support systems, career pathways, characteristics of women superintendents, leadership styles, barriers, and school board discrimination. Common themes voiced in 10 to 19 dissertations (23\% to $40 \%$ ) were clustered into the categories of cultural and societal expectations, the glass ceiling, racial discrimination, age, and search procedures. Thirty-five themes were included one to nine times in dissertations (2\% to $21 \%$ ) and considered by the researchers as minor. Displaying issues related to women superintendents highlights concerns and encourages solutions.

Keywords: dissertations, gender, leadership, superintendents, women.

\section{Introduction}

The term superintendent refers to the chief executive officer or leader of a school system. Historically and currently, in the U.S., most school superintendents are male. The numbers of women superintendents in the U.S. are low but showing growth with about 13 percent documented by Glass in 2000, 22\% in 2006 illustrated by Glass and Franceschini (2007), and 24.1\% as noted in a 2011 study completed by Kowalski, McCord, Petersen, Young, and Ellerson. It stands to reason since numbers of women superintendents are so low, research in this area is vast and a topic of many current dissertations. One assumes candidates seeking doctorates are emerging researchers providing the field with reviews of current literature and are focusing on gaps noted in the literature.

One methodology encouraging in-depth review of dissertations is content analysis. The methodology, content analysis, was chosen since it was a close analysis of the presence of words and/or concepts within a set of texts. Content analysis is a quantitative or qualitative methodology depending on its use. Through a content analysis of contemporary dissertations, it is expected literature available about women superintendents is prevalent since the numbers of women superintendents are lagging. Content analysis of dissertations should reveal much about the current state of research related to women superintendents.

${ }^{*}$ Professor, Stephen F. Austin State University, USA.

${ }^{\dagger}$ Associate Professor, Stephen F. Austin State University, USA. 
Beginning in 2016, Gresham and Sampson implemented close study employing content analysis of 2014 - 2016 U.S. dissertations located in ProQuest, and the researchers completed three distinct studies with this data. In the first study, quantitative content analysis was employed. The researchers focused on who were publishing about women superintendents as indicated in dissertation reference lists, what types of publications were the authors using to disseminate research as revealed in reference lists, and what were the major themes (concepts) displayed in the literature review headings of dissertations. The summative content analysis approach was employed and only manifest content analysis (a type of summative content analysis) was used as the researchers identified and quantified certain words or content in the dissertations (Hsieh \& Shannon, 2005). A second study continued the implementation of manifest content analysis as researchers reviewed all current (last five years) peer-reviewed articles located in Google Scholar, Academic Search Complete, WorldCat, and Education Resources Information Center (ERIC) to determined which of the cited major authors in the first study were continuing to publish articles about women superintendents and what other authors not cited in the $2014-2016$ dissertations were currently publishing in this area. Again, researchers were only concerned with quantifying certain words or content. Since these two studies did not display a close look at the current themes (fundamental concepts) displayed in the literature reviews of the 2014 - 2016 U.S. dissertations, Gresham and Sampson believed further analysis of the literature reviews of the dissertations was warranted. The first study only quantitatively studied theme through the frequency of word usage noted in the headings of the literature reviews, and the researchers desired to delve more deeply into the content of the literature reviews to ascertain the major themes (underlying meanings of the content). To achieve this mission, the researchers moved from simply exploring the frequency of word usage to a qualitative summative latent content analysis as described by Hsieh and Shannon (2005).

The purpose of this third study was to determine the themes displayed in the literature reviews of 2014-2016 U.S. dissertations pertaining to women superintendents located in ProQuest, an online database that indexes, abstracts, and provides access to dissertations and theses. As dissertations are often the most current literature available that extensively examines the research on one topic, dissertations were chosen for the content analysis. The research question guiding this study was "What were the major themes (concepts) pertaining to women superintendents displayed in the literature review sections of 2014 2016 U.S. dissertations located in ProQuest?"

\section{Literature Review}

Since the focus of the study was women superintendents, feminist theory and gender inequality provided the conceptual framework for this study. Gender inequality related to unfairness and/or unequal access for women to the superintendency (Curthoys, 2015). Gender inequity in the U.S. is common in 
the field of education and in the role of the superintendent (Young, 2005; Kowalski, McCord, Petersen, Young, \& Ellerson, 2011). The U.S. society has formulated norms for female behavior, considered female the weaker gender, and these norms impact women in the superintendency (Tavris, 1992; Skrla, 2000). Feminist theory is connected to social problems, trends, and issues neglected by the dominant male viewpoint within social theory. Thomas (1997) believed assuming different gender roles was not biological but more often a result of social conditioning. Feminist study is a research methodology pertaining to issues often overlooked or marginalized (Brooks and Hess-Biber, 2007). Feminist theory principles included in this study were (a) commitment to ending gender inequality; (b) review of gendered practices; (c) support for epistemological diversity (Nelli, 2014).

To prepare for this study, the researchers reviewed literature pertaining to gender inequity, barriers confronting women seeking the job of superintendent, and traits exhibited by women superintendents since these categories permeated the dissertation literature reviews of the previous two studies. Content analysis methodology was included to deepen the researchers understanding of which type of content analysis was needed and to bolster the rationale for why content analysis was chosen as the methodology for dissertation close review. Following is review of these areas.

\section{Gender Inequity}

Women experience marginalization due to gender when considering obtaining the superintendency (McLean, La Guardia, Nelson, \& Richards, 2016). Generally, leadership jobs, such as the superintendent, do contain women; more often, women hold the position of secretary, clerk, and care providers (Acker, 2006). Gender inequity was revealed in unequal pay, but Acker (2006) discovered these inequitable practices were fluid and changing. Inequity is still prevalent in education and in the role of superintendent as revealed by Acker (2006) and Glass, Björk, and Brunner (2000). In a study of nine women superintendents, Whitaker (2006) discovered all experienced gender bias. Supporting Whitaker's findings, Bañuelos (2008) surveyed 35 women superintendents in California to determine how gender bias affected their jobs and personal lives. Bañuelos found this group of women were aware of gender bias and believed bias affected them. These women felt disrespected and their authority challenged. The women revealed gender was a topic raised when talking with peers, the board, and the community. Many women superintendents stated they experienced emotional and physical abuse (2008).

Often displayed during the superintendent hiring process, is gender inequity. In a study of superintendent search and selection procedures, Tallerico (2000) revealed hiring practices limited access for minority males and women. In contrast, Wiggins and Coggins (2001) reviewed 15 school districts in Oklahoma to discover if school board members preferred men over women for the job of superintendent. School board members reviewed six resumes (three for women and three for men) for factious candidates. After the school board moved through 
the screening process, Wiggins and Coggins revealed gender was not a factor in superintendent selection. Although, Wiggins and Coggins' research showed a positive trend around gender inequity, women face barriers men do not.

\section{Barriers Confronting Women Seeking the Job of Superintendent}

Often, barriers deter women from entering the job of superintendent. In a study conducted in 2009, Derrington and Sharratt found barriers women faced to obtaining the superintendency were overwhelming and very similar to their 1993 study although the rankings of these barriers changed. Often self-imposed, barriers are related to family responsibilities, lack of mobility, and raising children. Gender and societal expectations often halted women from pursuing the job of superintendent. Women with children from early childhood through high school age were the lowest percentage of women in the superintendency (Derrington \& Sharratt, 2009).

Low self-efficacy is another barrier displayed by women as revealed by Muñoz, Pankake, Ramalho, Mills, and Simmonsson (2014). Dobie and Hummel (2006) discovered women often question their capacity to hold the job of superintendent. In addition, these researches relayed that finance management is an area woman do not have confidence in achieving, and this belief deters women from seeking the job. Although this questioning of capacity may not be warranted because women usually have more expertise in curriculum and instruction, and there is more demand for academic accountability in schools today. This skill should be an advantage for women.

A critical barrier for women is school board members and their search procedures. Muñoz et al. (2014) indicated school board members viewed women as poor finance managers and for this reason, not good candidates to lead districts. Search firms are oftentimes employed to locate candidates for the job of superintendent. Muñoz et al. found search firms weed out women from the process (2014). Unwritten criteria are utilized to hinder the selection of women candidates (Skrla, Reyes, \& Scheurich, 2000). It is documented barriers do exist for women seeking the job of superintendent, but those achieving and/or seeking the job have characteristics different from men.

\section{Traits and Challenges of Women Superintendents}

Women exhibit characteristics different from men, and these differences impact the superintendency. In a 2000 study, Glass listed reasons why women face challenges in seeking the job of superintendent: (1) they are not in jobs normally leading to the office of superintendent; (2) women are not preparing for the role: (3) they do not have interest or experience in finance; (4) personal relationships are barriers; (5) school boards usually do not hire women; (6) reasons why women enter the field are different than in times past; and (7) women are older when they enter administration. Derrington and Sharratt (2008) examined the characteristics of 15 women superintendents in Indiana to discover if they exhibited the normal profile of most superintendents and what characteristics 
enhanced their pursuit of the role of superintendent. Derrington and Sharratt discovered these women superintendents had higher qualifications than males, and they delegated more. Additionally, Derrington and Sharratt showed that characteristics of a strong work ethic, the influence of mentors, tenacity, and independence contributed to their success. In 2016, Superville discussed why few women lead school districts and stated many find the job of superintendent unattractive. Superville further revealed that a normal pathway to the superintendency is the role of secondary principal, and women are usually elementary principals.

Networking and mentoring differ for women from men. Women compared to men have fewer mentoring and networking opportunities (Muñoz et al., 2014) and often network for social support. Men network to advance their careers (Singh, Vinnicombe, \& Kumra, 2006). Peters (2010) agreed that women superintendents seek support and friendship, but Peters added that women often have men and women mentors. Brunner and Grogan (2007) found women seeking the job of superintendent are more interested in utilizing networking and mentors more than those not seeking the role. Searby and Tripses (2006) and Whitaker (2006) revealed some women are reluctant to seek or mentor other women and resist mentoring opportunities. Limited networking is a characteristic and reason why women do not seek the superintendency (Superville, 2016). To add to the knowledge of women superintendents, the researchers employed summative content analysis methodology to ascertain the themes revealed in recent dissertations.

\section{Content Analysis}

Content analysis is a methodology to study trends and patterns used in document review (Knippendorff, 2004). Knippendorff also indicated that content analysis includes: (a) which data are analyzed; (b) how are they defined; (c) what is the population from which they are drawn; (d) what is the context relative to which the data are analyzed; (e) what are the boundaries of the analysis; and (f) what is the target of the inferences. Content analysis is described as a method to review texts and other data forms and a way to achieve relevant data from a thorough review of artifacts (Knippendorf, 2004; Leavy, 2007; Nelli, 2014). Hsieh and Shannon (2005) indicated there were three distinct types of content analysis: conventional content analysis (to describe a phenomenon); directed content analysis (to identify key concepts through using existing theory or prior research); and summative content analysis. According to Hsieh and Shannon (2005), summative content analysis has two types. The first is manifest content analysis that is used when the researcher desires to quantify certain words or content with the purpose of determining the frequency of words or content. The second is latent content analysis. This methodology refers to the process of interpreting the content to determine the underlying meaning of the content.

Over time, other researchers have employed content analysis as a methodology in reviewing theses and dissertations. Weber (1990) implemented content analysis to examine themes displayed in dissertations pertaining to women superintendents. 
Horton and Hawkins (2010) studied 252 dissertations to discover if doctoral programs in social work included intervention research. Mete (2014) employed content analysis to discover theories and models displayed by nursing students and advisors in dissertations. In a study of 1993 to 2014 theses, Dirliki, Aydin, and Akgün (2016) employed content analysis to assess cooperative learning. Atmaca (2016) conducted a content analysis of theses and dissertations to compare contextual features. The methodology of content analysis is an authentic and proven manner to analyze dissertations.

\section{Methodology}

Gresham and Sampson (2017) completed two previous studies reviewing 2014 - 2016 U.S. dissertations published in the ProQuest database. In the first study, the researchers determined who were the major researchers cited, what types of documents were cited, and what were the dominate themes displayed in the headings of the literature reviews. The first study found there were eight major authors cited across the 43 dissertations pertaining to women superintendents: Bjork, Brunner, Glass, Grogan, Kowalski, Shakeshaft, Skrla, and Tallerico. Gresham and Sampson further revealed that the most common avenue for publishing research was peer-reviewed articles with books, chapters, and other sources following in this order. Through manifest content analysis, Gresham and Sampson discovered the most common themes exhibited in the literature review headings were women/female, superintendents, leadership, school districts, and $\mathrm{men} / \mathrm{male}$.

The second study extended the research and sought to determine if the major authors found in the first study continued to publish about women superintendents and if other authors were researching and publishing about women superintendents over the last five years (2009 - 2016). Bjork, Brunner, Glass, Skrla, and Tallerico exhibited no further publications, Grogan had four, Kowalski had one, and Shakeshaft had five. The analysis of current research yielded nine additional publications of other authors related to women superintendents.

This third study included an extensive content analysis of $2014-2016$ U.S. dissertation literature reviews published in the ProQuest database. The first study only analyzed the headings of the literature reviews. For this third study, the researchers employed summative content analysis and both types (Hsieh \& Shannon, 2005). First latent content analysis was implemented through interpreting the words and phrases displayed in the literature reviews to discover the underlying meanings. Then the researchers through analysis, categorized the common meanings into categories and named the themes. This thematic analysis pinpointed and recorded the important concepts displayed in the literature reviews. Then as the researchers counted the frequency the named themes were displayed across the dissertations, manifest content analysis was used.

The study process included analyzing the 43 literature reviews of the first study. Each dissertation literature review text was copied into a Word table. The table categories included the title of the dissertation, full text of the 
literature review, theme noted, and text support. Each literature review text was analyzed and as segments of text were located illustrating underlying meanings, that text was copied was placed in the text support column. A theme name was crafted to describe the underlying meaning and placed in the theme column for each text segment. After 43 literature reviews were read and individually analyzed, the tables were combined into one Word table. The table was then sorted by themes. An analysis of the sorted themes was conducted, and themes were analyzed once again, combined, and reworded as needed to discover the displayed themes (underlying meanings). Next, the themes were categorized according to the frequency they were displayed.

\section{Findings/Results}

The current study revealed a 159-page table reflecting themes addressed in the dissertation literature reviews. Table 1 indicates the themes discovered, the number of times themes were displayed, and the percentages of times themes were displayed. The researchers considered major themes as displayed 20 to 36 times, common themes as displayed 10 to 19 times, and minor themes as displayed 1 to 9 times.

Table 1. Number and Percentages of Themes of Literature Reviews

\begin{tabular}{|l|c|c|}
\hline Theme & $\begin{array}{c}\text { Number of Times the } \\
\text { Theme was Displayed }\end{array}$ & $\begin{array}{c}\text { Percentage the } \\
\text { Theme was } \\
\text { Displayed }\end{array}$ \\
\hline $\begin{array}{l}\text { Low numbers of women } \\
\text { superintendents }\end{array}$ & 36 & 84 \\
\hline Gender inequity & 34 & 79 \\
\hline $\begin{array}{l}\text { History pertaining to women } \\
\text { superintendents }\end{array}$ & 30 & 70 \\
\hline $\begin{array}{l}\text { Support systems including role } \\
\text { model, mentoring, and networking }\end{array}$ & 30 & 70 \\
\hline $\begin{array}{l}\text { Career pathways to the } \\
\text { superintendency }\end{array}$ & 29 & 67 \\
\hline $\begin{array}{l}\text { Characteristics of women } \\
\text { superintendents }\end{array}$ & 22 & 51 \\
\hline Leadership styles of women & 21 & 49 \\
\hline Barrier - family & 20 & 47 \\
\hline School board discrimination & 20 & 40 \\
\hline Culture and society expectations & 17 & 40 \\
\hline Glass ceiling & 17 & 40 \\
\hline $\begin{array}{l}\text { Preparing for the role of } \\
\text { superintendent }\end{array}$ & 17 & 33 \\
\hline Relationship building & 14 & 33 \\
\hline $\begin{array}{l}\text { Research need around women } \\
\text { superintendents }\end{array}$ & 14 & 33 \\
\hline $\begin{array}{l}\text { Search procedures to fill the job of } \\
\text { superintendent }\end{array}$ & 14 & 47 \\
\hline
\end{tabular}




\begin{tabular}{|c|c|c|}
\hline $\begin{array}{l}\text { Preparation programs for the } \\
\text { superintendency }\end{array}$ & 13 & 30 \\
\hline Overcoming barriers & 12 & 28 \\
\hline Racial discrimination & 12 & 28 \\
\hline Age entering the superintendency & 10 & 23 \\
\hline Instructional leadership & 10 & 23 \\
\hline Good ol' boy practice & 9 & 21 \\
\hline Barrier - self-imposed & 8 & 19 \\
\hline $\begin{array}{l}\text { Choice in the job of } \\
\text { superintendency }\end{array}$ & 8 & 19 \\
\hline Spirituality & 8 & 19 \\
\hline $\begin{array}{l}\text { Women superintendents helping } \\
\text { other women }\end{array}$ & 8 & 19 \\
\hline Power & 7 & 16 \\
\hline Balancing family and work & 6 & 14 \\
\hline Change agents as superintendents & 6 & 14 \\
\hline Fiscal management & 6 & 14 \\
\hline $\begin{array}{l}\text { Resiliency of women } \\
\text { superintendents }\end{array}$ & 6 & 14 \\
\hline Politics & 5 & 12 \\
\hline Compensation discrimination & 4 & 9 \\
\hline $\begin{array}{l}\text { Role conflict for women } \\
\text { superintendents }\end{array}$ & 4 & 9 \\
\hline Rural school districts & 4 & 9 \\
\hline Stereotyping & 4 & 9 \\
\hline $\begin{array}{l}\text { Working conditions of the } \\
\text { superintendent }\end{array}$ & 4 & 9 \\
\hline Barrier - mobility & 3 & 7 \\
\hline Emotional control & 3 & 7 \\
\hline Job satisfaction & 3 & 7 \\
\hline Role of the superintendent & 3 & 7 \\
\hline $\begin{array}{l}\text { Time expectations of the } \\
\text { superintendent }\end{array}$ & 3 & 7 \\
\hline Urban districts & 3 & 7 \\
\hline Acceptance from others & 2 & 5 \\
\hline Courage & 2 & 5 \\
\hline Diversity & 2 & 5 \\
\hline Gatekeepers blocking women & 2 & 5 \\
\hline Reflective practice & 2 & 5 \\
\hline Stress of the job & 2 & 5 \\
\hline Decision making willingness & 1 & 2 \\
\hline Evaluations by school boards & 1 & 2 \\
\hline Life-long learning & 1 & 2 \\
\hline Negotiation & 1 & 2 \\
\hline $\begin{array}{l}\text { Professional organization } \\
\text { membership }\end{array}$ & 1 & 2 \\
\hline Self-awareness & 1 & 2 \\
\hline Student-focused & 1 & 2 \\
\hline
\end{tabular}


Following is analysis of the major themes displayed (20 to 36 times). The most displayed theme was "low numbers of women superintendents" with $84 \%$ of the dissertations including this theme. Text in the literature reviews discussed how men out numbered women in the role of superintendent with Hispanic and women from African descent exhibiting even lower numbers than White women. One example of a statement displayed was, "women attaining the superintendency is characterized as sluggish with only $24.1 \%$ of women in the U.S. occupying the superintendent position." Other statements revealed the disparity of women of Hispanic or African descent. Examples were "2\% of superintendents in 2010 were female" and "African American females do not obtain the position as quickly as White women." This major theme mirrored the findings of Glass (2000), Glass and Franceschini (2007), and Kowalski, McCord, Petersen, Young, and Ellerson (2014). This finding supported the need for feminist study as stated in the conceptual framework for this study.

The second major theme was "gender inequity." The identification of this theme directly connected to this study conceptual framework of feminist theory and gender inequity in that the literature review analysis of this study revealed gender remains a social problem for women in the superintendent role, and women are still treated differently and unfairly when compared to men. The study findings supported the research of McLean, La Gluardia, Nelson, and Richards (2016); women experience marginalization when trying to enter the superintendency. Also, this study supported the research of Skrla, Reyes, and Scheurich (2000) and Muñoz et al. (2014); women are discriminated against when they seek the role of superintendent. Gender inequity was included in $79 \%$ of the dissertations. Gender inequity was revealed through terms such as discrimination, stereotyping, and different treatment due to gender. Some examples of comments revealing these topics were "leadership positions are hindered by discrimination and stereotyping," "those hiring desire to reproduce a new leader in their own [male] image," and "women are treated differently from male superintendents because of their gender."

History of women superintendents and support systems for women seeking or achieving the superintendency were themes noted in 30 or $70 \%$ of the dissertations. The literature reviews presented an overview of women in the superintendency. Many discussed a woman superintendent pioneer, "In 1909, Ella Flagg Young was named superintendent of the Chicago Public School system in Chicago, Illinois." Literature reviews displayed discussions of women superintendents from the $19^{\text {th }}$ century to present day.

Themes related to support systems included topics such as role models, mentoring, and networking. This finding directly related to the research of Bruner and Grogan (2007), Munoz et al. (2014), and Superville (2006). Women have fewer networking opportunities, and women seeking the job of superintendent are interested in using mentors and networking. Some examples of text displaying the need for support systems were "the lack of role models and mentors is significant" and "the need to build strong relationships and to network with other superintendents was deemed crucial." Another statement discussing how some women superintendents seek support systems after achieving the job of 
superintendent was "most female superintendents seek support systems after getting appointed," and this statement showed how lack of support systems negatively impacted women, "many women did not acquire the position because of a lack of encouragement to prepare for the position."

Career pathway was a themed contained in 29 or $67 \%$ of the literature reviews, and this theme directly aligned with the research of Glass (2000) and Superville (2016). The content in this theme, career pathway, related to how the pathway to the role of superintendent is different for women when compared to men and more complicated. One statement revealing this underlying meaning was, "the career paths of women seeking the superintendency may be more complex and arduous than male counterparts." The usual career path to the top job is high school principal to superintendent, but for women this path is different. Two statements showing this were "fewer women apply and are hired for high school principals" and "the most common experience reported for women superintendents is the principalship at the elementary level." A common career path for women is that of assistant superintendent to superintendent as is revealed by this statement "the female superintendent is $40 \%$ more likely to have served in the position of assistant superintendent before assuming the top leadership position than are males."

Characteristics of women seeking or holding the job of superintendent were displayed in 22 or $51 \%$ of the literature reviews. "Older than men," "single," "widowed," or "divorced" were terms used to describe women superintendents. Other terms were "care," "courage," "intuition," "vision," "determination," and "commitment." When in the role, women superintendents are viewed as leaders who are "change agents," "spiritual," "lifelong learners," and "servant leaders." These themes aligned with the findings of Glass (2000) and Derrington and Sharratt (2009); women are older and exhibit stronger work ethic.

Related to characteristics is leadership style, and this theme appeared in 21 or $49 \%$ of the literature reviews. The leadership style for women superintendents was described with terms such as "transformational," "collaborative," "nurturing," and "situational." It was revealed a more collaborative and inclusive style may be viewed as negative. An example comment was "while the participatory style of female leaders may be a strength, this style allows the leader to be more open to criticism." As dissertations revealed, women leaders are usually skilled in instruction, and when they lead, women are often "learning-centered" and focused on "curriculum and instruction."

Displayed 20 or $47 \%$ of the time in literature reviews were the barrier of family and school board discrimination. These comments displayed how family was viewed as a barrier to seeking the role of superintendent, "the number one barrier was conflict between career and family demands," and "in our society, the woman's role is that of mother and household caretaker." As was stated in the literature reviews, "balancing work and family life" is a reality for many women seeking the superintendency. Glass (2000) also discovered that personal relationships were barriers for women. School board discrimination was also displayed in the research of Glass (2000), Skrla, Reyes, and Scheurich (2000), and Muñoz et al. (2014). As documents showed, most "school boards are 
composed of males." An example statement showing how boards discriminate against women was, "boards fail to consider female applications." Reasons revealed for why school boards discriminate against women were "women are less proficient with the demands of school budgets;" women were viewed as "caring, listening, and nurturing, not strong;" and "women allow emotions to influence decisions."

Other common themes displayed were: (1) cultural and societal expectations (40\%); (2) the glass ceiling (17\%); (3) preparing for the role of superintendent (17\%); (4) relationship building (14\%); (5) research need in the area of women superintendents $(14 \%)$; (6) search procedures $(14 \%)$; (7) preparation programs for the superintendency (13\%); (8) overcoming barriers (12\%); (9) racial discrimination (12\%); (10) age entering the superintendency (10\%); and instructional leadership (10\%). As these common themes were clustered, cultural and societal expectations, the glass ceiling, racial discrimination, age, and search procedures were viewed as barriers for women. Some example statements to support these themes were "societal views about proper roles for men and women may still extend into the educational realm creating barriers for women in the superintendency; " the glass ceiling apples to any situation where there is a perception that upper management positions are primarily consumed by men, and that no matter how hard women try, they are constantly met with barriers that thwart their progress;" women of African descent and Latina "wade through the reefs of perception about race;" women "remain in the classroom for seven to 10 years resulting in a late start to leadership;" and "the historical maledominated conceptualization of the position of superintendent influences the way school boards define selection criteria."

Finally, thirty-five themes were mentioned in literature reviews one to nine times ( 2 to $21 \%$ ) and considered by the researchers as minor themes according to the 43 literature reviews. Some of these were: 1) good old' boy practices, 2) self-imposed barriers, 3) spirituality, 4) power, 5) politics, 6) role conflict, 7) job satisfaction, 8) women helping other women, 9) location of districts, and 10) negotiation.

\section{Discussion}

The purpose of this study was to determine the major themes pertaining to women superintendents in the literature review sections of $2014-2016$ U.S. dissertations located in ProQuest. Review of the 43 dissertations' literature reviews revealed a 159-page table indicating themes covered. Major themes displayed 20 to 36 times in literature reviews (47 to 84\%) were low numbers of women superintendents, gender inequity, history of women superintendents, support systems, career pathways sought by women, characteristics of women superintendents, family as a barrier, and school board discrimination. Eleven common themes displayed 10 to 19 times ( 23 to $40 \%$ ) were clustered in these categories: cultural and societal expectations, the glass ceiling, racial discrimination, age, and search procedures. Thirty-five themes were displayed nine times 
or less (2 to $21 \%$ ) with good ol' boy practices the highest (nine times) and decision making, school board evaluation, life-long learning, negotiation, professional organization membership, self-awareness, and student-focused the lowest (one time).

The major themes related to topics often researched in the field. The theme low numbers of women superintendents was displayed the most (in $84 \%$ of the dissertations) and was supported by researchers such as Glass (2000), Glass and Franceschini (2007), and Kowalski et al. (2014). Gender inequity was a theme viewed in $79 \%$ of the dissertations and was supported by authors such as Glass, Björk, and Brunner (2000), Acker, (2006), Bañuelos (2008), and McLearn, La Guardia, Nelson, and Richards (2016). Support systems (noted in $70 \%$ of the dissertations) included role models, mentoring, and networking, and these concepts were often studied by authors such as Muñoz et al. (2014) and Brunner and Grogan (2007). The finding of how career pathways differ for men and women (noted in 67\% of the dissertations) was supported by authors such as Glass (2000). The characteristics of women superintendents, how they differ from men, and leadership styles was noted in $49 \%$ to $51 \%$ of the dissertations and researched by those such as Derrington and Sharratt (2008) and Superville (2016). Barriers, often cited in current research, was included in the literature reviews, and the main barrier noted in the dissertations was family (47\% of the dissertations). Researching family barriers were authors such as Derrington and Sharratt (2009).

\section{Conclusions}

More research is warranted in the field of women superintendents going beyond the major and common themes displayed in the 43 dissertation literature reviews. Themes were very similar across most of the dissertations. Literature reviews often did not identify gaps in research supporting additional reasons why women do not enter the field of superintendent or are not successful in their attempts to achieve the role.

The numbers of women superintendents are low, and one way to highlight the disparity is through dissertation study. Emerging researchers must be pushed to go beyond common themes such as gender inequity, support systems or lack of, school board discrimination, career pathway differences, and barriers. Learning to identify gaps instead of relaying often researched themes found in current literature is critical to discover more about why women do not enter the superintendency and why the number of women superintendents remains low.

\section{References}

Acker, J. (2006). Inequality regimes: Gender, class, and race in organizations. Gender and Society, 441-464.

Atmaca, C. (2016). Comparison of Hedges in M. A. Theses and Ph.D. dissertations in ELT. ZfWT, 309-325. 
Bañuelos, M. V. (2008). Breaking the silence: Gender bias in the top ranks. Leadership, 28-30.

Brooks, A., \& Hesse-Biber, S. N. (2007). An invitation to feminist research, In S. N. Hesse Biber \& P. L. Leavy (eds.), Feminist Research Practice. Thousand Oaks, California: Sage Publications.

Bruner, C. C., \& Grogan, M. (2007). Women leading school systems: uncommon roads to fulfillment. Rowman and Littlefield Education, Lanham, Maryland.

Curthoys, A. (2005). Gender studies in Australia: A history. Australian Feminist Studies, 19-38.

Derrington, A.B., \& Sharratt. G. 2009. Female superintendents: Breaking barriers and challenging life styles. Delta Kappa Gamma Bulletin, 8-12.

Dirliki, K. A., \& Akgün, L. (2016). Cooperative learning in Turkey: A content analysis of theses. Educational Sciences: Theory and Practice, 1252-1273. doi 1012738/estp. 2016.4.0142.

Dobie, D. F., \& Hummel, B. (2006). Successful women superintendents in a genderbiased profession. Equity and Excellence in Education, 22-28. doi: 10.1080/10 66568010340204.

Glass, T. E. (2000). Where are all the women superintendents? Retrieved from https:// bit.ly/2wydaxT.

Glass, T. E., Björk, L., \& Brunner, C. D. (2000). The 2000 study of the American school superintendency. Arlington, Virginia:American Association of School Administrators.

Glass, T. E., \& Franceschini. L. A. (2007). The state of the American superintendency. Alexandria: American Association of School Administrators.

Hsieh, H. \& Shannon, S. E. (2005). Three approaches to qualitative content analysis. Qualitative Health Research, 15(9), 1277-1288. doi: 10.1177/1049732305276657.

Horton, E. G., \& M. Hawkins. (2010). A content analysis of intervention research in social work doctoral dissertations. Journal of Evidence-Based Social Work, 377386. doi: 10.1080/15433710903344066.

Kowalski, T. J., McCord, R. S., Petersen, G. I., Young, P. I., \& Ellerson, N. M. (2011). The American school superintendent 2010 decennial study. Lanham, Maryland: Rowan and Littlefield Education.

Knippendorff, K. (2004). Content analysis: An introduction to its methodology ( $\left.2^{\text {nd }} \mathrm{ed}\right)$. Sage Publications, Newbury Park, California.

Leavy, P. L. (2007). The feminist practice of content analysis. In S. N. Hesse-Biber \& P. L. Leavy (eds.), Feminist Research Practice: A Primer. Thousand Oaks, California: Sage Publications.

McLean, L.LLa Guardia, A. C., Nelson, J. A., \& Watts, R. E. (2016). Incorporating Adlerian and feminist theory to address self-objectification in couple's therapy. Newbury Park, California: Sage Publications.

Mete, S. (2014). Using a nursing theory or a model in nursing PhD dissertations: A qualitative study from Turkey. International Journal of Nursing Knowledge, 62-72.

Muñoz, A.J., Pankake, A., Ramalho, E., Mills, S., \& Simmonsson, M. (2014). A study of women central office administrators and their aspirations to the superintendency. Educational Management Administration and Leadership, 764-784.

Nelli. D. K. (2014). Gender representation in U. S. Ed.D. dissertations: A feminist content analysis. Doctoral Dissertation. Retrieved from PDX Scholar https://bit.ly/2I9ncuI.

Peters, A. (2010). Elements of Successful Mentoring of a Women School Leader. Leadership and Policy in Schools, 108-129.

Sampson, P., \& Gresham, G. (2017). Women superintendents research: 2014-2016 Dissertation Content Analysis and Current Cited Author Data. Research on Women

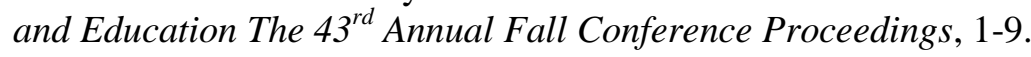


Searby, L., \& Tripses, J. (2006). Breaking Perceptions of "Old Boys Networks": Women Leaders Learning to Make the Most of Mentoring Relationships. Journal of Women in Educational Leadership, 2006, 179-195.

Singh, V., Vinnicombe, S., \& Kumra, S. (2006). Women in Formal Corporate Networks: An Organizational Citizenship Perspective. Women in Management Review, 458482.

Skrla, L. (2000). The social construction of gender in the superintendency. Journal of Education Policy, 15(3), 293-316. doi: 10.1080/02680930050030446.

Skrla, L., Reyes, P., \& Scheurich, J. J. (2000). Sexism, silence, and solutions: Women superintendents speak up and speak out. Educational Administration Quarterly, 44-75.

Singh, V., Vinnicombe, S., \& Kumra, S. (2006). Women in Formal Corporate Networks: An Organizational Citizenship Perspective. Women in Management Review, 458482.

Superville, D. R. (2016). Few women run school districts. Why? Education Week, 2016, 9-10.

Tallerico, M. (2000). Gaining access to the superintendency: Headhunting, gender, and color. Educational Administration Quarterly, 18-43.

Tavris, C. (1992). The mismeasure of woman. New York: Simon \& Schuster.

Thomas, S. A. (1997). Theory and practice in feminist therapy. Social Work, 447-454.

Weber, R. P. (1990). Basic content analysis $\left(2^{\text {nd }}\right.$ ed.). Newbury Park, California: Sage Publications.

Whitaker, J. E. (2006). Women in the middle: A qualitative study of the leadership experiences of women central office administrators. Doctoral dissertation \#3226986.

Wiggins, T., \& C. Coggins, C. (2001). Gender bias in superintendent selection: A projecttive analysis. Journal of Educational Research, 115-120.

Young, M. D. (2005). Shifting away from women's issues in educational leadership in the US: Evidence of a backlash? International Studies in Educational Administration, 31-42. 